\title{
3
}

\section{A work of love: Awareness and expressions of emotion in a Borneo healing ritual}

\section{Clifford Sather}

Andrew Beatty (2014: 546) is no doubt right in asserting that '[f]or most of our discipline's brief history ... emotion has not been a theoretical focus', emotions being, as he puts it, 'just too imponderable for functional methodology' (p. 548). Recent decades, however, have dramatically altered this picture, and studies of emotion have emerged as a significant topic of anthropological theorising (Beatty 2005, 2010; Kapferer 1979; Levy 1973, 1984; Lutz 1988; Lutz and White 1986; Rosaldo 1984; Shweder and LeVine 1984; Wilce 2004). My purpose in this chapter is to explore the role of emotion in an Iban rite of healing, focusing in particular on what is arguably the most imponderable of all human emotions, love, looking at how this is understood by the Iban and how 'love' was made to serve, in a distinctively Iban ritual setting, as an instrument of healing.

First, however, it is useful to outline Iban notions of 'love' and briefly touch on the role that emotions associated with these notions traditionally played in Iban society, particularly in practices related to healing, illness and wellbeing. ${ }^{1}$

1 The Iban are the most populous Dayak, or indigenous, non-Muslim group of western Borneo. Tracing their origins to the Kapuas River basin of present-day Kalimantan Barat, the great majority of Iban now live in the Malaysian state of Sarawak, where, in 2010, they numbered over 700,000 


\section{The Iban vocabulary of love}

There is no single term in Iban that, by itself, approximates the Western concept of 'love'. Instead, there exists a set of terms that, taken together, capture the concept's central range of meaning. Each of these terms denotes what we might call a different variety of Iban love. In Iban-English dictionaries, the two words that are most frequently glossed as love are rindu' and kasih (cf. Bruggeman 1985: 65; Richards 1981: 141, 309; Scott 1956: 154; Sutlive and Sutlive 1994: 642). The most common meanings of rindu' are 'like', 'love', 'be pleased by' or 'made glad by' (Richards 1981: 309). For example, iya rindu' nginti means 'he likes to fish [with a hook and line]'. When used to describe an emotional state-that is, as in rindu' ati or pengerindu' ati-the term rindu' refers to a feeling of 'joy', 'pleasure' or 'gratitude' such as a person experiences when in the presence of someone whose company they find pleasurable. Kasih, on the other hand, refers to love in the sense of 'caring for', 'supporting' or 'fulfilling the needs of [another]'. Hence, kasih is often translated, in addition to 'love', as 'kindness', 'sympathy' or 'compassion'. For example, minta' kasih means 'to ask a favour', while the transitive verb form, kasihka, means 'to pity', 'feel sorry for' or 'be kind to'. Another Iban term with a very similar meaning is sayau. Although more often translated as 'pity', sayau also connotes 'love' in the overlapping sense of 'sympathy'. Together, these three terms are regularly used by the Iban to describe the feelings that prompt a person to perform acts of kindness, such as caring for those who are ill. All three are what Catherine Lutz (1988: 145) has called 'emotions of strength', meaning that those who experience them are 'empowered' by the experience and so see themselves as capable of 'fulfilling the needs of others'. Rindu', however, focuses more on mutuality, the ability of partners to satisfy each other's needs, ${ }^{2}$ while kasih and sayau focus more on the unequal capacity of one person to gratify the needs of others.

\footnotetext{
(Department of Statistics Malaysia 2012). A smaller number, estimated at 14,000, continue to live in West Kalimantan, chiefly along the low-lying border region known in Iban as the Emperan or 'Flat Land' (Wadley 2004; Wadley and Kuyah 2001: 716-19). During the past century, Iban have also migrated northward from Sarawak to Sabah and the independent Borneo state of Brunei Darussalam (Sather 2004: 623).

2 In this sense, rindu' resembles the Hawaiian term léa, famously discussed by Sahlins (1985: 3-4) in Islands of History, except that, unlike le'a, its meaning does not extend to sexual gratification.
} 
Reflecting an interactive sense of selfhood, in which persons define themselves primarily by their relationships with others, the Iban tend to associate the needs to which feelings of kasih and sayau are associated with bonds of kinship, social support, health and care-giving. Thus, love, especially in the sense conveyed by these two terms, is seen as a highly positive emotion, one that motivates persons to offer social support and provide care to others. While those who provide care are highly respected, Iban society is also notably competitive. Individuals and families seek to advance their status relative to others by virtue of their material achievements and, in so doing, they regularly evoke love in a very different sense-one related more closely to notions of erotic or sexual love.

The terms rindu', kasih and sayau are rarely used in connection with romantic love, sexual attraction or desire. Instead, separate terms are used to describe emotions associated with sexual love. These terms rarely find their way into Iban-English dictionaries, very likely because they lack the qualities of idealisation that English speakers generally associate with romantic love (see, for a discussion of the latter, Averill 1985). Instead, the connotation of these terms is notably physical and body-centred. To have sex with another is to 'mingle', 'cohabit' (gulai) or 'lie down together' (gali). During intercourse, sexual partners are said to become setubuh, a 'single body'. The most common term used in Iban to describe sexual love as an emotional state is $k a^{\prime}$, a shortened form of deka', meaning, literally, 'to want' or 'desire'. Thus, $k a$ ' is commonly used, in a shorthand way, to refer to an agreement to marry (Richards 1981: 71). An even stronger term is keran (or pengeran, n.f.), meaning 'urge' or 'craving'. Unlike rindu', $k a s i h$ and sayau, $k a$ ' and keran are socially ambiguous. Although sexual gratification is seen as a source of pleasure, sexual desire, when translated into action, represents a potential source of personal danger, ${ }^{3}$ and, in the form of adultery, is regarded as a cause of almost certain social disruption (Sather 1994). Erotic love is also associated metaphorically with warfare and headhunting-formerly sources of male prestige. Consequently, sex is also often described using a language of combat or is referred to euphemistically as ngelaban, meaning, literally, 'to fight' or 'do battle [with]' (Sather 1994: 11). At the same time, erotic love is culturally valued

3 For example, it is considered mortally dangerous for a widow or widower to continue to pine for a deceased spouse after the final rites of mourning have taken place (Sather 1978: 317-18). Similarly, spirit assailants often appear to their victims as irresistibly attractive human beings of the opposite sex and their illness-causing attack is frequently experienced as a form of sexual seduction (see Freeman 1967; Sather 1978). 
as a pleasurable pursuit in itself. Thus, traditional storytelling, wordplay and most song genres and forms of verbal entertainment centre on themes of sexual love, longing and flirtation.

\section{Love and visibility: To see and be seen}

The Iban tend to be highly sensitive to the interpersonal, as opposed to the purely subjective, dimensions of emotions. This is particularly so in the case of the emotional states that we have identified here with 'love'. What is particularly notable in this regard is that the varied senses of love conveyed by the terms rindu', kasih, sayau, ka' and keran, as emotions experienced or expressed within a context of interpersonal relationships, are all similarly perceived by the Iban as sources of potential attraction. To be activated, however, love-whether as sympathy, gladness, compassion or sexual longing - requires that the object of this love be visible to the other. 'Visibility' (pandang) is thus the key that unites these different varieties of Iban love. Visibility reveals and so-when matched with perceptions of need, beauty, pleasure or feelings of physiological arousal-activates love as a source of interpersonal attraction. To see and to be visible to others are, in Iban cultural terms, preconditions for love's operation. Hence, love in whatever form it takes is associated with the acts of seeing, of making oneself seen and of being seen by others. The central concept here, pandang, means not only 'visible', but also 'show', 'display', 'exhibit', 'reveal' or, literally, 'shine forth' (cf. Richards 1981: 248). To display or show oneself means to make oneself visible-a condition that causes others to take notice and so, potentially at least, be attracted to us. In this sense, pandang also refers to a condition of power, as in the cognate term pemandang, referring to 'love charms', objects that are imbued with the power to compel others to see and so to admire those who possess them.

Love in this visually related sense-as a set of emotions activated by the sight of, or working through the gaze of, the other-applies not only to relations of care-giving, sexual liaisons and marriages, but also to political relations and ties of mutual obligation. Traditional Iban society, although competitive, was relatively egalitarian, lacking formal institutions of prescriptive ranking and clearly defined lines of chiefly power (Freeman 1981; Sather 1996). Instead, individuals, families and kindred groups actively competed with one another for prestige, influence and authority. 
Leaders were essentially self-made men of prowess who attracted followers by virtue of their personal accomplishments, generosity and outward signs of spiritual favour. Renown, like love, was similarly associated, not with formal duty or inherited right, but with visibility. Each person was said to be the 'source' (pun) of his or her own renown (nama). To gain recognition required, in this visual idiom, that a person, literally, 'show himself' (mandangka diri) ${ }^{4}$ - that is, that he demonstrate his worth through his actions and demeanour. For men, the traditional zenith of achieved status was represented by the orang tau' serang, tau' pandang - war leaders whose achievements in the past were made 'visible' (pandang) by a lifetime of 'showing themselves's by repeatedly demonstrating their worth in ways that were overtly visible to others. Thus, competitive advantage, whether in love, politics or war, went to those who made themselves noticed.

While visibility activates love as a force of attraction, by contrast, illness, ageing and death are associated with its inverse-invisibility-and so threaten all that love represents.

\section{The Sugi Sakit}

The healing ritual that concerns us in this chapter was called the Sugi Sakit and was performed until its demise, some 25 years ago, by Iban priest bards in the Betong division of western Sarawak. ${ }^{6}$ The ritual was performed primarily for the elderly, those nearing the end of their lives who were chronically ill or whose afflictions were considered beyond the scope of shamanic healing. Until the recent, and now all-but-complete, conversion of the Saribas Iban to Christianity, ritual life in Saribas was largely the work of ritual specialists, most notably priest bards (lemambang), shamans (manang) and soul guides (tukang sabak) (see Sather 2001: 5-13). Of these specialists, shamans were the primary healers. However, particularly severe forms of affliction were thought to be treatable only by the direct

\footnotetext{
4 Mandangka, like pemandang, derives from the same root, pandang (v.f., mandang), meaning 'visible'.

5 Serang means, literally, 'attack' (Richards 1981: 342). In the late eighteenth and early nineteenth centuries, the orang tau' serang, tau' pandang were regional war leaders who led their followers on raids and were responsible for defending the territorial boundaries of the regions within which their leadership was recognised (see Sather 1996: 79-80). They were, in Wolters's terms (1999: 18-21), classic 'men of prowess'.

6 As far as we know, the Sugi Sakit was never performed outside this area by Iban priest bards, either in other parts of Sarawak or in the neighbouring Indonesian province of Kalimantan Barat.
} 
intervention of the gods (petara), and so were the special domain of the priest bards whose primary ritual function was that of invoking the gods and bringing them into direct contact with their human clients.

I first witnessed a performance of the Sugi Sakit in June 1977, during my first days of fieldwork in the Saribas. Although it made a deep impression, nearly 30 years passed before I was able to begin a serious study of the ritual. In June 2003, with support from the Tun Jugah Foundation, ${ }^{7}$ I began field recording the ritual with my wife, Louise, and our Iban co-worker, Jantan Umbat. ${ }^{8}$ In the late 1970s, when I began fieldwork, many families living along the Paku tributary of the main Saribas River identified themselves as Christian. However, longhouse ritual life was still little affected by Christianity and the Sugi Sakit and other forms of traditional healing remained very much alive. All of that was beginning to change, however, and, over the next 20 years, much of what I describe in this chapter ceased to exist, including, by the 1990s, the Sugi Sakit itself. Meramat anak Empong, the famous priest bard who had performed the Sugi Sakit I witnessed in 1977, died in December 1988. By 2003, when I began this study, more than a decade had passed since the Sugi Sakit was last performed. To carry out our work, it was therefore necessary to find a priest bard who had regularly performed the ritual in the past and commission a new performance. Fortunately, the son of one of my past informants, Renang anak Jabing, had become a priest bard like his father, and, when I first met him in the early 1980s, he was already a regular performer of the Sugi Sakit. In June 2003, Louise, Jantan and I arranged to work with Renang at his home in Tarum longhouse, near Debak. There, over six nights, we recorded a complete two-night version of the Sugi Sakit with detailed commentary. The following year, we visited Dit longhouse, the former home of Lemambang Meramat, and there recorded a second version of the Sugi Sakit, sung by two men who, although not priest bards themselves, had studied with Meramat. Most of the material contained in this chapter comes, however, from our work with Lemambang Renang. ${ }^{9}$

7 I am grateful to the Tun Jugah Foundation and, in particular, to its founding director, Tan Sri Datuk Amar Leonard Linggi Jugah, for the generous support that made this study possible.

8 Jantan Umbat, who played a crucial part in this study, is a retired Iban educator, novelist and scholar, and was at the time a senior member of the Tun Jugah Foundation research staff. At present, he is Research Officer and Officer-in-Charge of the Ethnic Culture Unit in the Sarawak Ministry of Social Development. I am grateful to Jantan, Louise, Oliver Venz, Bob Blust and Jim Fox for their comments on earlier drafts of this chapter.

9 Our working sessions are documented in some 40 hours of tape recordings, with extensive conversational commentaries. These have been deposited and are available in the Tun Jugah Foundation archives in Kuching, plus digital copies and a full transcription of our recording sessions with Renang (Sather and Umbat 2004). 


\section{Ritual as work, narrative and drama}

Iban describe social performances such as the Sugi Sakit as pengawa', a term that derives from the root word gawa', meaning, literally, 'work', 'business' or, more generally, 'anything important or serious that has to be done' (see Richards 1981: 96). Farm work, for example, is pengawa' (Sather 1992: 108), but so, too, are what we would call 'rituals' in English. ${ }^{10}$ As a kind of work, the Sugi Sakit was the exclusive province of Saribas Iban priest bards, although other participants, including the ritual's sponsors and a lay audience, were also essential in carrying it out. In performing this work, priest bards, like other ritual specialists, did so primarily by using words to create what the Iban call a main, meaning, literally, a 'play', 'drama' or 'entertainment'. Like the English word 'play', main connotes, in particular, a dramatic enactment or entertainment composed primarily in words. As Lemambang Renang observed, in performing the Sugi Sakit, priest bards 'treat the sick by means of [our] voice' (ngubat orang ke sakit ngena' nyawa). ${ }^{11}$

Compared with other rituals performed by Saribas priest bards, the Sugi Sakit was unique in two important respects. First, it incorporated within its main the singing of a long narrative epic. This epic, in varying forms, was also told as a longhouse entertainment on non-ritual occasions, often by lay storytellers. Second, the narrative itself was essentially a love story or epic romance. Hence, the singing of a love story was an integral part of the Sugi Sakit. By incorporating it directly into the ritual's main, a love story thus became, the Iban say, not 'merely an entertainment' (main aja') or 'diversion' (merindang), but a purposeful act, something serious that had to be done if the Sugi Sakit were to succeed as a work of healing.

\section{A healing romance: The Bujang Sugi epic}

For a priest bard, Renang explained, performing the Sugi Sakit meant both bemain (lit., 'enacting a drama') and becherita ('telling a story [cherita]').

The principal characters in the Sugi story are not ordinary human beings but Orang Panggau (lit., 'people of Panggau')—culture heroes and heroines who inhabit a raised world known as Panggau, or Panggau Libau,

10 For more on Saribas Iban notions of ritual, see Sather (forthcoming).

11 In Iban, nyawa means, literally, 'mouth', but also 'voice', 'breathe' and even 'life'. 
located between 'this world' (dunya tu'), the visible world of everyday human existence, and the 'sky' (langit), the upper realm of the most powerful of the Iban gods. While described as 'people' (orang), the Orang Panggau are also referred to as bunsu antu, benevolent spirits (antu), who are believed to have once lived together with the ancestors of the Iban in this world. Displaying all of the physical and psychological characteristics of human beings, the Orang Panggau also possess superhuman powers, including immortality and, for some, like Keling, the leader of the Orang Panggau, the power to transform their appearance at will. Bujang Sugi, the hero of the Sugi epic, is, in actuality, Keling. As Keling, he represents the embodiment of masculine prowess and physical perfection. Unlike the upper world of the gods, the Panggau world interpenetrates with this world, so that human beings sometimes encounter the Orang Panggau, particularly at mountain springs or waterfalls. Moreover, Keling at times enters this world, often appearing as a cobra, and here in the past he acted as a spirit-patron of Iban warriors and leaders, as did the heroines, Kumang and Lulung. In the Iban oral epics (ensera), Keling appears as a wanderer, who, in the course of his travels, assumes many disguises, but whose magical powers, appearance and bearing are such that men everywhere recognised him at once as a leader, while women fell instantly in love with him. His powers of attraction transcend different orders of being. Thus, his lovers (ambai) included not only women of the Orang Panggau world, but also female animal spirits, and, throughout the Sugi story, these various spirit-lovers appear at crucial times, providing the hero with timely warnings or with charms of invulnerability.

According to Renang, the serious work of the Sugi story occurs at the beginning and end of the narrative, while the middle episodes were highly variable and sung primarily for entertainment. Thus, the opening of the story recreates the predicament of the priest bard's patient and members of the sick person's longhouse. As with illness, infirmity and prospects of death, here, there is an absence of visibility. The longhouse in which the story is set is unable to attract visitors. No newcomers cross the top of its entry ladders, its betel nuts go unharvested and its cooked rice spoils because there are no visitors to feed and entertain. There are no young men coming to court the young women of the longhouse and the community's ageing leader, Father of Rimbu', has no young successor to whom he can impart his knowledge. To rectify this situation, his wife, Mother of Rimbu', calls together the eligible young women of the longhouse and gathers from them their love charms. These charms, called 
pemandang, embody the power of pandang - literally, 'visibility', but here, more fittingly, 'the power of attraction'. This first episode Renang called ngayunka pemandang ('to arouse [or, lit., "fan"] the power of attraction'). As it concludes, Mother of Rimbu' activates the young women's love charms and, from the rooftop of the longhouse, releases their power into the air. Erotic love thus serves as the primary means of supplication that draws the hero, Bujang Sugi, into his own narrative.

As the next episode opens, the hero, at home in his own longhouse, is overcome with longing (pengusang ati). And so, he departs for the longhouse of Mother and Father of Rimbu'. Here, disguising his appearance, he presents himself as a stranger and is adopted by Mother and Father of Rimbu'. As he is nameless, the couple name him Bujang ('Bachelor'/'Young Man') Sugi. In actuality, however, he is Keling. In telling Keling's story, the priest bard maintains the hero's deception and never explicitly identifies him as such; however, as the story progresses, he increasingly hints at his true identity. The story itself, in its basic outline, represents a version of the classic Austronesian myth of the stranger-king, telling of a visitor from abroad whose arrival transforms the society he visits (see Fox 1995: 217-19, 2008; Sahlins 1981, 2008, 2012). In this case, however, unlike most versions of the myth, the hero does not institute a new line of kingship, or otherwise alter the structure of his hosts' society, but, instead, serves as a temporary link between those who commission the telling of his story and the upper-world gods, making it possible for the latter to intervene directly in the this-world rite of healing the priest bard is in the process of performing.

A characteristic feature of stranger-king myths is that the transformative power of the stranger-being foreign to the society he visits-must be captured and in some way incorporated into the society of his hosts (Fox 2008). Typically, this capture comes about by means of a sexual union between the male visitor and a local woman (or women). The transformative power of the foreign thus complements the reproductive power of the autochthonous. ${ }^{12}$ In the Sugi story, as soon as the hero enters Father of Rimbu's longhouse, he begins at once to court the longhouse beauty, Endu Dara ('Maiden'/'Young Woman') Semanjan. Semanjan, however,

12 This is an element of the Sugi story as well. After the priest bard completes singing the main epic, concluding with Sugi's descent into this world, he typically sings a brief epilogue, called Anak Bujang Sugi, in which he describes the birth of a son to Sugi and Sedinang, Sugi's departure and his eventual reunion with his son. 
is literally a femme fatale. All who attempt to court her perish because she is in mourning for a husband who has recently disappeared and is presumed dead. This husband, however, is none other than Keling, who appeared once before, similarly as a stranger. Sugi is therefore what Fox (2008: 202) has called a 'returning outsider'. He came as a stranger before to Father of Rimbu's longhouse and in his earlier appearance he married Semanjan and so is immune to her lethal powers. Keling's object this time, however, is not Semanjan, but, rather, Sedinang, the most beautiful of all the Orang Panggau women. As Renang explained, Sedinang is, in reality, Kumang, Keling's wife in Iban epic tradition, while Semanjan is her cousin and rival, Lulung. In the Sugi story, she appears as the daughter of Father of Rimbu's brother, Sentukan 'The White-Haired', and, on their adopted son's behalf, Father and Mother of Rimbu' travel to Sentukan's longhouse to arrange the couple's marriage.

This marriage takes place in Father of Rimbu's longhouse. Here, however, Semanjan, in a jealous rage, challenges her rival, Sedinang, to a series of contests to determine which of them is the most comely. Although Sedinang easily wins these contests, Sugi refuses to cease his nocturnal visits to Semanjan's sleeping place, so Sedinang decides to return to her parents' longhouse. Sugi follows in pursuit and their journey turns into a contest of wills. In the meantime, enemies of the Orang Panggau, learning of the couple's journey, prepare an ambush. Forewarned, Sugi single-handedly takes on the enemy warriors, defeats them all and takes the heads of their leaders. The couple, now reconciled, arrive at Sentukan's longhouse, where Sugi is welcomed as a victorious warrior. What occurs next depends on the length of the performance commissioned by the sponsors. If the performance is to continue over a second night, the story is now temporarily suspended. The following night, it begins with a series of additional adventures and battles. After the last of these battles is fought, or, in the case of a one-night performance, immediately following the couple's arrival at Sentukan's longhouse, Bujang Sugi calls a meeting of his father-in-law's followers and announces his intention to hold a ritual celebration (gawai) to honour the gods for making his victories possible, inviting as his guests Selempandai, Biku Bunsu Petara and other upperworld gods associated with healing.

At the conclusion of the Sugi epic, as it is sung during the Sugi Sakit, Bujang Sugi leaves the narrative world in which it is set and, together with his Orang Panggau followers, and accompanied by Selempandai and the other Iban gods of healing who have come to attend his gawai, he enters 
the visible world in which the ritual is being performed, and here, in the words of the priest bard's main, he and the others intervene directly in the ritual by treating the patient with their medicines and special healing powers. All of this happens at the conclusion of the hero's gawai. Before his guests return home, Sugi informs them that they are now invited by human beings to participate in a work of healing that is taking place in the human world below. And so, now as the invited guests of the sponsors of the Sugi Sakit, the gods and spirit heroes accompany Bujang Sugi as he descends to this world. Here, in the words of the priest bard's main, they treat the patient with their medicines and chants. In this way, a narrated ritual is merged momentarily with the actual ritual, and the two become for a brief moment one and the same.

As soon as he finishes singing of Bujang Sugi's descent, the priest bard briefly leaves his swing and goes to where the patient is installed at the centre of the longhouse gallery. There he briefly re-enacts what Bujang Sugi and the gods have just done by treating the patient himself. His role as a storyteller thus anticipates his actions as a healer, and, in the end, both roles merge, as the priest bard briefly assumes the part of the principal actors in the story he has just related.

\section{The role of emotions, thought and awareness in the Sugi Sakit}

The main Sugi Sakit was intended not only to compel the gods and spirit heroes to make themselves present as unseen healers; its performance, as a dramatic entertainment, also acted on the emotions and, through the emotions, on the awareness and behaviour of those who participated in the ritual.

'The Iban', as the late Robert Barrett (2012: 114) asserted, 'feel emotions in their body' - and not only emotions, but also, one might add, desires and intentions. For the Iban, the 'body' (tubuh), while outwardly visible, is said to contain within it invisible interior spaces. These spaces, particularly those 'inside the chest' (di dalam dada), are the location of bodily organs that are believed to be the seat of emotions, feelings, thoughts and intentions, hence of the faculties that most fully define a person in everyday social and psychological terms (Sather 2001: 48-9). 
James Matisoff, in a pioneering essay entitled 'Hearts and minds in South-East Asian languages and English' (1986: 8), notes that in most European languages expressions referring to emotional states and other psychological phenomena usually make no explicit reference to the locale within which these phenomena unfold. In contrast, many languages of East and South-East Asia treat psychological phenomena as an 'overt class' by means of what Matisoff calls 'psycho-collocations'-morphologically complex expressions, one constituent of which is a morpheme that refers specifically to the locale within which psychological processes occur (1986: 8). Not only are 'psycho-collocations' abundant in East and South-East Asian languages, but also this locale, when arrayed across a 'mind-body continuum', tends to be situated towards the 'body' end of the spectrum - that is, it refers less to 'mind', 'soul' or 'spirit' than it does to 'visceral organs' of the body (Matisoff 1986: 14). While Matisoff's essay concerns primarily Sino-Tibetan languages, Goddard (2001: 167) has suggested that the same general feature also holds for the Austronesian languages of peninsular and island South-East Asia. More recently, Robert Blust has surveyed Austronesian expressions relating to emotions, particularly those that are similarly constructed as metaphorical extensions of body-part terms (2013: 321-7). Among the most prevalent of these expressions are those based on reflexes of the Proto-MalayoPolynesian (PMP) morphemes * qatay ('liver') and *qapeju ('gall bladder'). Expressions based on the first of these terms are particularly numerous and tend to be associated with emotions generally, while the second tend to be associated more specifically with judgement, commonsense and courage (Blust 2013: 325-6). Both terms figure significantly in Iban, particularly the first of the two.

Thus, in Iban, most expressions associated with feelings and other psychological phenomena make use of the morpheme ati, a reflex of the PMP * qatay, which the Iban explicitly identify with the heart-liver region of the body. More specifically, the term ati derives from the word atau, which, strictly speaking, refers to the 'liver'. By extension, however, ati also encompasses the heart, which in Iban is generally described as the tungkul atau (lit., 'the flower bud of the liver'), which, as a physical organ, the heart closely resembles. As Barrett (2012: 115-16) notes, Iban speakers typically use the word ati in a way that encompasses both the heart and the liver, as well as, at times, other organs contained within 
the chest (di dalam dada) or upper interior of the body. ${ }^{13}$ In everyday speech, virtually all emotions, desires and states of feeling are expressed through the use of the term ati. For example, gaga ati means 'happy'; pengerindu' (rindu') ati, 'glad'; penenguk (tenguk) ati, 'desire', 'yearn for'; pengusang (kusang) ati, 'long for', 'be infatuated by'; tusah ati, 'sad'; sinu'ati, 'pity'; penakut (takut) ati, 'frightened'; pengerawan (rawan) ati, 'nervous', 'fearful'; pengirau (irau) ati, 'worried', 'anxious'; pemerani (berani) ati, 'courageous'; tembu' ati, 'contented'; penaluk (taluk) ati, 'obedient'; pengangkun (angkun) ati, 'steadfast', 'loyal'; chemuru ati, 'jealous'; pengaru' (garu') ati, 'suspicious'; bebulu ati, 'ill-natured'; begedi' (gedi') ati, 'hate'; ensiban ati, 'resentful', 'bearing a grudge'; panas ati, 'hot-tempered'; and pedis ati, 'angry'. Iban is a Malayic language and, semantically, the Iban term ati parallels in many ways its Malay cognate, hati. ${ }^{14}$ Anatomically, most Malay writers identify hati with the liver, which Karim (1990: 26), for example, describes as 'a mysterious organ ... believed to control the moods and emotions of humans and ... command their psyche'. While Goddard similarly identifies hati with the liver, metaphorically, he glosses it as 'heart'. However, as he observes, hati is not semantically identical, being 'significantly more active, and more cognitive' (Goddard 2001: 167). Like the Iban term ati, it is used particularly in expressions referring to emotions aroused or activated within the context of interpersonal relationships. In contrast to the metaphoric use of 'heart' in English, it is also more 'dynamic', being, as Goddard (2001: 178-9) puts it, a place where 'things happen'. Hence, like ati in Iban, it is the primary seat not only of feelings, but also of cognition and awareness, and so is used, like ati, in many contexts where 'mind' would be a more appropriate English gloss than 'heart' (Goddard 2001: 179).

13 This is consistent with the derivation of ati from atau. While the term's connection with 'liver' is clear, in Proto-Malayo-Polynesian, as Blust notes, the word for heart was not an independent bodypart term, but also had a botanical referent (2013: 325). Barrett (2012: 116) has proposed 'heart/ liver' or 'heart/liver complex' as a translation of ati. Here, for the sake of convenience, I gloss the term simply as 'heart'. Atau, on the other hand, is culturally significant for the Iban primarily in the context of divination (senaga). For a concise, but detailed, account of the meaning of atilatau in Iban, see Ensiring et al. (2011: 47-8).

14 In Iban, the phoneme / $h /$ never occurs in an initial position. While a number of metaphorical expressions in Malay based on the term hati have ati counterparts in Iban, others do not. For example, ambil hati (fetch + heart) in Malay and ngambi' ati (fetch + heart) in Iban have roughly the same meaning: 'to attract' or 'win the affections of'. Similarly, bakar hati (burn + heart) in Malay and panas ati (hot + heart) in Iban both mean 'hot-tempered'; busok hati (rotten + heart) in Malay and jai ati (bad + heart) in Iban both mean 'quick to take offence', 'ill-natured'; and sakit hati (sick + heart) in Malay and pedis ati (hurt + heart) in Iban both mean 'annoyed', 'angry'. On the other hand, besar hati (big + heart) in Malay has a slightly different meaning to besai hati (big + heart) in Iban. In Iban, there are no precise counterparts of the Malay kecil hati (small + heart) or of puteh hati (white + heart), while there are no apparent counterparts in Malay of the Iban expressions pengaru' ati (scratchy + heart), bebulu ati (to have hair + heart) or ensiban ati (splinter/thorn in the flesh + heart). 
In addition to ati, other parts of the body are also identified with feelings, especially in the poetic language register (leka main) used by Iban ritual specialists in composing their ritual main. One of these is empedu, a reflex of PMP * qapeju, meaning, literally, 'gall' or 'gall bladder'. In compound expressions, empedu represents the locale of feelings of shame or embarrassment (malu). In contrast to a number of other Austronesian languages, in Iban, empedu is not directly associated with courage or judgement, except, in the latter case, in a negative sense. Thus, nadai empedu malu (not + gall bladder + shame) means to do what is shameless - that is, to act without common sense or respect for social convention. Another term frequently used in metaphorical extensions is tulang ('bone/s'). Tulang is associated in particular with feelings of strength, energy or resolve, or, inversely, of weakness, exhaustion or idleness. Thus, tulang aku lembut (lit., 'my bones are soft') means to feel weak or exhausted. Feelings may also be linked to the lungs (lempuang), spleen (tekura') and stomach (perut). The recessive, or 'interior' (di dalam), nature of these organs of feeling is often reinforced in the poetic language of the main by additional expressions that describe them as 'enclosed' or 'fenced in' (kandang)—for example, by the 'lungs' (lempuang), 'chest' $($ dada $)$ or 'ribs' (kerigai). ${ }^{15}$

In the special language register (leka main) used in the composition of ritual main, lines and stanzas are structured primarily through the recurrent use of final-syllable rhyme (see Sather 2001: 163-5). Thus, in this register, expressions relating to the emotions often occur in the form of rhyming pairs. For example, malu ('embarrassment') is regularly paired with empedu ('gall bladder'), irau ('worry') with atau ('liver'), tekenyit ('surprise') with kulit ('skin'), kusang ('longing') with lempuang ('lungs'), mari' ('quarrelsomeness') with lepi'('folds') plus tandan lempuang ('stem of the lungs'), kesal ('startled') with jungkal ('flower bulb') plus kandang dada ('heart'; lit., 'flower bulb enclosed by the chest') and sinu' ('pity') with leku' ('coils') plus perut ('intestines'; lit., 'coils of the stomach').

The active verb form of ati, beati, means 'to feel', 'sense' or 'experience [feelings]', while the expression beati-ati means 'to be aware', 'conscious' or 'mindful'. To experience conflicting or divided feelings is to have, literally, 'two hearts' (dua ati), while persons who share the same feelings

15 The recessive nature of the ati and other organs of feeling contributes to their ambiguous status. On the one hand, these organs are indisputably parts of the body; on the other hand, they are not directly visible from outside the body, and hence they are also allied with the unseen. 
or intentions are said to be of 'one heart' (seati). A 'complete' or 'finished heart' (tembu' ati) signifies contentment; a 'bad heart' (jai ati), ill will; a 'hurt heart' (pedis ati), anger; a 'hot heart' (panas ati), a hot temper; a blocked heart (pengalit ati), puzzlement; a 'scratchy heart' (pengaru' ati), suspiciousness; a 'hairy heart' (bebulu ati), hatred; a 'splinter' or 'thorn in the flesh heart' (ensiban ati), resentment, holding a grudge; a 'disturbed heart' (pengirau ati), anxiety; and a 'big heart' (besai ati), 'boastfulness'.

To be gerai (in 'good health') as opposed to sakit ('sick') is to feel energetic, clear-headed and strong. These feelings make themselves known through the bodily senses and so are registered chiefly in the ati as the principal seat of sentient awareness-that is, they are made manifest through a work of beati-ati. But, not only are the symptoms of illness and good health experienced within the body, they also are apprehended and acted on by the body. Thus, for the Iban, feelings are described as experienced not within a disembodied 'mind', but directly in various parts of the body, chiefly in the ati, but also in other parts. Indeed, as Barrett (2012: 114) has noted, the Iban language has no term specifically for 'mind', or for its adjectival form, 'mental'. This has important implications in terms of how the Iban explain the effectiveness of healing rituals such as the Sugi Sakit. While traditional anthropological explanations of how healing rituals work have typically relied on a mind/body duality, seeing rituals as working on the mind in ways that effect physical changes in the body, ${ }^{16}$ Iban explanations, by contrast, typically focus on a seen/unseen duality (see Barrett 1993; Sather 2012a: xxiii-iv). While states of good or ill health are experienced by the body, and apprehended by the ati, their source is potentially far more complex, reflecting not only conditions internal to the body, but also relationships between unseen components of the self, such as the 'soul' (semengat), and other beings and powers, both seen and unseen, that are thought to be at work outside the body (Sather 2001: 48-74).

For the Iban, the body is also the site of intentionality. The usual way of saying 'I want to' in Iban is ati aku deka', literally, 'my heart wants to'. Again, however, intentions are similarly diffuse, and may derive not only from the ati, but also from other parts of the body, especially those associated with particular actions, such as the eyes (mata) with seeing and the mouth

16 There are, of course, exceptions. In recent years, many anthropologists have embraced the concept of 'embodiment' and so have explicitly rejected explanation framed in terms of mind/body dualities (see, for example, Csordas 1990, 1996). 
(nyawa) with speaking. For example, a newly recovered patient, who has just regained a sense of wellbeing, is described as one whose 'mouth now wants to eat, [whose] legs now want to walk' (nyau benyawa deka' makai, bekaki deka' bejalai). Like intent, hesitancy or reluctance (lembau) is also experienced in the body, typically in the liver (atau), while failure to execute an intended action may be attributed to a conflict between the at $i$ and the particular body part responsible for the action. For example, 'my heart wanted to, but my bones were weary' (ati aku deka', tang tulang aku lelak) means 'I wanted to go, but was too tired'.

Thoughts likewise are said to arise within the body. In Iban, the verb berunding means 'to think', and, in everyday speech, the usual way of saying 'I think' is ba runding aku, literally, 'according to my thoughts' (runding). However, in conversational Iban, thought and speech are often conflated. The common expression ku' aku (lit., 'says I') also means 'according to me', 'in my opinion' or, simply, 'I think'. Consequently, the term jaku', or its shortened form, $k u$ ', means not only 'speak', but also 'think'. By contrast, ku' ati aku (lit., 'says my heart') or ba ati aku ('according to my heart') means, more reflectively, 'I thought to myself'. In this connection, berunding means not only 'to think', but also, more collectively, 'to deliberate', 'discuss' or 'talk [things] over [with others]'. Barrett thus argues that the Iban see thinking, because of its links to speech, more 'as a social rather than [an] introspective process' (2012: 117).

While Western concepts of personhood tend to privilege the internal mental life of an individual, which is seen as disembodied, taking this disembodied mentality to be a defining feature of a person, for the Iban, the body itself is 'mentalised' - that is, it is seen as the field in which mental life operates. Consequently, personhood is defined less in terms of the uniqueness of an individual's internal mental life and more in terms of his or her interactions with other persons, with the body, as seen from without, serving as its visible representation. ${ }^{17}$ Thus, the body, unmediated by any notion of a disembodied mind, is seen as the field in which feelings, emotions and volition are experienced, apprehended and acted on. While the heart/liver is the principal locale in which all of this occurs, it is not the sole source of cognition and action. Other parts of the body are also involved. Speech, touch, turning the eyes and moving within

17 The term tubuh ('body') is thus used by Iban speakers in much the same way that English speakers use the term 'person'. For example, berapa iku' tubuh dia means 'how many persons are there [over there]?'. 
the environment all require other parts of the body, such as the mouth, teeth, fingertips, arms, legs and bones; in short, one's entire corporeal being is involved in taking in and acting on the world-a perspective clearly reflected in Iban ethno-semantics.

This kind of highly embodied sense of feeling, thought and action has been described for other Austronesian societies as well. Robert Levy, for example, writes of Tahitians (1984: 221):

[W] hen asked to describe such matters as anger, desire, fear, and so on, villagers say that their 'place' is in the 'intestines' ... These feelings can arise spontaneously in the intestines or they may be stirred up by some thought from the head, or by something that is seen by the eyes or heard by the ears ... The feeling can lead to action directly, but this usually produces a bad result. It should first be thought over in the head, the seat of proper judgment, prior to taking action.

In contrast to the Tahitians, for the Iban, the process of 'thinking' is not the work of the 'head', ${ }^{18}$ but occurs both in the ati and outside the body in the interactive realm of speech. Ideally, feelings and intentions should be subject to verbal deliberation before they are translated into action, particularly if this action is likely to affect others.

As Bruce Kapferer (1995: 134) reminds us, no matter how embodied our awareness may be, it is never limited to processes internal to the body alone. 'All human beings are oriented within a life-world of other human beings', their actions directed towards the horizons of the various life worlds they and others share (Kapferer 1995: 134-5). This sharing of life worlds is crucial to understanding how the emotions, intentions and awareness work in processes of healing.

\section{The body, ageing and illness}

Despite its centrality, the body tends to disappear from awareness when functioning unproblematically. It is mainly at times of dysfunction that it tends to seize our attention. Illness, pain and other forms of bodily

18 However, as Barrett (2012: 116) notes, in addition to the heart/liver, many Iban, particularly younger, educated Iban, also identify thinking with the 'brain' (untak), especially in regard to forms of thinking associated with formal education. In contrast to the Iban, the people with whom I did earlier fieldwork, the Sama Dilaut, like the Tahitians, similarly associate thinking with the head (see Sather 1997: 296). 
affliction not only call attention to the body, they also direct our attention to particular parts of the body-for example, to an injured ankle or a chest in pain (see Leder 1987: 173). In this way, pain interrupts our links to the external world and to the life worlds we share with one another. As Elaine Scarry (1985: 33) writes: 'As in dying and death, so in serious pain the claims of the body utterly nullify the claims of the world.' Thus, intense pain, like the process of dying, is 'world destroying' (Scarry 1985: 29). Bodily affliction 'tends to induce ... isolation' and brings about what Drew Leder has called 'a spatio-temporal constriction' of the self (1987: 181). However, although 'it disrupts our intentionalities', it:

never leads to a complete collapse of the world. It is our nature, as beingsin-the-world, to inhabit a significant continuum of space and time, projects and goals. However, the new world into which we are thrust by pain has a constricted aspect ... We are no longer dispersed out there in the world, but suddenly congeal right here. (Leder 1987: 181-2)

This inwardness of pain places it, Leder argues, always 'a little behind what can be seen or touched. It takes over our perceptual field and yet eludes us' (1987: 182). Much of Iban healing is about overcoming this elusiveness. Shamans, for example, by focusing directly on the body, overcome this inwardness by palpating their patients, feeling their bodies with their fingertips for invisible pain or illness-causing objects lodged beneath the surface of the skin. By removing these objects, they make them visible, often as tiny stones (Sather 2001: 124-5), and so they not only disclose them visually, but also remove them from the body. Because of the inwardness of pain, space, too:

loses its normal directionality. Physical suffering constricts not only the spatial, but also the temporal sphere. It pulls us back to the here but also calls us back to the now. Pain thus exerts a 'centripetal' force, gathering space and time inward to the center. (Leder 1987: 182-3)

Serious illness and infirmity also tend to restrict the mobility of the sufferer's body, possibly rendering it no longer capable of acting in the world. As a result, '[t]he body, immobilized and restrained', becomes, Kapferer (1995: 139) argues:

no longer vital in the production of consciousness. It becomes the boundary of a consciousness given up to itself in virtual reverie ... that projects back into itself ... within the closure of the body. Not only does it exhaust meaning within itself, but also such a confined consciousness attacks its prison, the body itself. 
Curing thus becomes a process that Kapferer describes as an intentional re-extension' of embodied awareness back into the life worlds the sick person formerly shared with others (1995: 137). The narrative and staging of the Sugi Sakit worked to produce just such a re-extension, re-establishing the directionality of space and time, and so refocused the patient's awareness outward, beyond the boundaries of their body, on a shared life world evoked by the priest bard's main. Everything in the Sugi narrative drew the listener into this external world and its attractions. Mountains soar into the heavens and longhouses stretch across the horizon. War boats miraculously skim over the water or even fly. The priest bard's use of hyperbole and extravagant imagery in the Sugi Sakit aroused the listeners' interest and drew them into an idealised and seemingly timeless world of heroic adventures and romance. The story and the larger verbal drama in which it was set thus worked on the emotions as a powerful counteragent to the constrictive, world-obliterating effects of illness and infirmity.

\section{The Sugi Sakit as a work of love: The aesthetics of pleasure and beauty}

In talking with Iban elders about the Sugi Sakit, many of them said that participating in the ritual 'made them feel joy' (ke ngasuh rindu')— that is, it literally 'made [them] feel love' (rindu'). Dari anak Alen, Lemambang Meramat's sister, for example, told us: ${ }^{19}$

For me, I don't know about others [aku, orang enda' mih nemu] - I don't know what others experienced in [their] hearts [enda' nemu ati orang]but, for myself, when he [the priest bard] performed it, I couldn't sleep [enggi' aku nama sida' iya (lemambang) bemain, aku endang enda' tinduk]. I truly loved it [rindu' endar ati]. That's why I couldn't sleep [nya' alai ke enda' tinduk].

Not only the Sugi story, but also the spectacle of the ritual itself aroused love:

The bard singing, the people taking part in the procession to welcome the gods, to welcome the shaman [gods] [orang bemain, orang ngalu petara, ngalu manang]. Oh, the women really looked magnificent wearing all their gear [oh balat ngepan indu' kau]! They really dressed up [endang

19 Interview, Rumah Dit, 4 August 2004. 
bengepan manah-manah]. It was a truly beautiful sight [mata pan rindu' ga (lit., 'the eyes were also made glad')]. I really loved it [ati pan rindu ga']. It made me want to be young again [tetenguk ka biak baru].

As a ritual drama, the main Sugi was intended to both cure the sick and bring pleasure to those who took part in the ritual. Participating 'helped the sick person get well' (nulung ngeraika orang ke sakit), but also caused those taking part 'to feel love' (ke ngasuh rindu'). Indeed, some described the Sugi Sakit as a 'ritual/work of love' (pengawa' rindu').

'Love', in contrast to pain, Scarry writes, affirms our capacity 'to move out beyond the boundaries of our body into an external, sharable world' (1985: 5). In contrast to sickness and ageing, love and perceptions of beauty not only maintain, but also intensify, our intentional links to the external world and to other human beings.

The aesthetic emphasis in the Sugi Sakit on entertainment, pleasure and beauty not only worked on the feelings of those taking part in the ritual, but also transformed the longhouse setting where the ritual took place. The gallery became a public gathering place. At its centre, the ritual's sponsors constructed a raised platform (panggau), ${ }^{20}$ partially encircling it with an enclosure of finely woven ritual cloth ( $\left.p u a^{\prime} k u m b u^{\prime}\right)$. This construction, in the special language of the priest bards, was called the meligai. The beauty of the cloth that formed the walls of this enclosure was said to attract the notice of the gods and spirits, while the structure itself was a sign to these unseen observers that human beings were holding a curing ritual to which they, too, were invited as 'guests' (pengabang). The meligai thus served as both a visual invitation and a sign of welcome. Its construction was followed by an offering ceremony (biau), after which offerings were placed in and around the structure and at the entrance to the outdoor platform (tanju'), where a divining pig was tethered for slaughter at the conclusion of the ritual. These offerings demarcated the stage on which the Sugi drama was enacted and served as primary points of contact between the gods and the ritual's human participants. They also provided the gods and spirits, in the words of the priest bard's main, with a sumptuous feast. As soon as this offering ceremony was over, the priest bard left the gallery and entered the sick person's family apartment. In so doing, he signalled the formal beginning of the Sugi Sakit. Inside the apartment, he began,

20 Note the semantic connection of panggau with the intermediating raised world of the Orang Panggau. 
for the first time, to sing as family members escorted the patient out on to the gallery. This journey, accompanied by gong music and the priest bard's singing, was deliberately slowed to allow the observing gods and spirits time to witness and react with compassion to what was occurring. Inside the meligai, the patient was installed on the platform and made comfortable with bedding and cushions.

One side of the meligai, through which the party entered with the patient, was left open. This faced a swing (tali wa) on which the priest bard sat as he sang the main Sugi Sakit.

The struggle to stay alive is a struggle to maintain one's extension out into the world. As Scarry points out, not only states of feeling, but also speech is important in this struggle. Oftentimes, she writes, 'the voice becomes a final source of self-extension; so long as one is speaking, the self extends out beyond the boundaries of the body' (Scarry 1985: 33). 'Verbal virtuosity' thus becomes, Scarry writes, 'a mode of survival' (1988: 33).

Speech, however, works the other way as well, as a source of self-extension not only for the speaker, but also for the listener. In the Sugi Sakit, verbal virtuosity was the special gift of the priest bard, not of the patient. It was the patient as a listener, however, who benefited. The main Sugi was not only poetically composed, it was also sung and enacted. Hence, the priest bard's main was made available to the senses through its theatrical presentation and the melodic qualities of the priest bard's singing, and so became an object of direct experience (see Sather, forthcoming). The musicality, rhyme and other aesthetic features of the priest bard's use of language brought the sensory, perceptible qualities of ritual speech (leka main) to the awareness of his audience, thereby playing on the 'ability of the listener to focus alternatively on meanings and sounds' (Urban 1996: 182). The sound dimensions of speech were heightened and so distracted the audience from a tendency towards what Urban has called 'referential consciousness', opening them instead to 'experiences other than those permitted by the overt meaning of words' (1996: 185). At the same time, sound foregrounded 'nonreferential signs, embodied experience, [and an] immediate encounter with the world' (Urban 1996: 185), and so exercised a magnetic pull, drawing the listener directly into the verbal drama that the priest bard created as he sang. Physical sound also points to the contrast between the seen and the unseen: between the hereand-now realm of the senses and the reality beyond this realm contained in verbal imagery and poetic language. The aesthetic emphasis on beauty, 
entertainment and pleasure was not incidental to the purpose of the Sugi Sakit, but, rather, contributed directly to the ritual's effectiveness and to that of the priest bards who in the past performed it.

\section{Compassion and visibility}

While love in the sense of gladness played a central role in the Sugi Sakit, it was love primarily in the sense of compassion that brought together the ritual's human audience and motivated them in carrying out the ritual as a work of healing. To love in the sense of kasih and sayau was to intervene, to respond to the needs of the patient by making oneself present.

For the Iban, the struggle to maintain life and recover a sense of wellbeing is understood, above all, as a struggle to see and remain visible. Hence, illness, infirmity and dying are the inverse of love and so are associated, as we have said, with invisibility and a severing of visual connections. The patient and, perhaps, their whole longhouse are no longer visible to the gods. Invisibility becomes both the cause and a consequence of bodily affliction. While the patient loses their awareness of the external world, others lose sight of the patient. Illness causes the sick person to withdraw from active involvement in the everyday life of the longhouse, oftentimes confining them to a sickbed. Although physically present, they become invisible to others. A major object of the Sugi Sakit was to reverse this diminished visibility by making the sick person a central focus of visual scrutiny. Consequently, the opening stage of the Sugi Sakit involved removing the patient from the relative seclusion of their family's apartment and installing them at the centre of the longhouse gallery. Here, the patient was ceremonially placed inside the meligai. Although enclosed on three sides by walls of ritual cloth, with upright spears forming its four corners, this enclosure was meant to safeguard the ailing patient, not to separate them from the rest of the community or to render them invisible. On the contrary, the walls of cloth were intended to attract notice, to arrest the eyes of all who beheld the structure, signalling to observers that, inside, it was a loved one, dangerously ill and in need of their care. Moreover, the meligai was not fully enclosed, but was open on one side. Its open side not only faced the priest bard's swing, but also was oriented towards what the Iban call the ujung ramu ('tip of the beams'). This orientation, relative to the long axis of the longhouse (see Sather 1993: 76-8), ensured the gods and spirit heroes would have to come completely inside the 
longhouse to gaze into the meligai, rather than merely 'peep in' from the nearest entrance, and that the priest bard would not have his back to them when they first entered. Thus, the structure was oriented in a way that was welcoming and not only invited visitors to approach the meligai, but also encouraged them to enter the enclosure itself and there attend to the patient inside.

The greater part of Iban healing-particularly that which was the work of the priest bards-was concerned with counteracting the centripetal effects of pain, ageing and illness. Pain and illness brought about an alienation from the body. Experiencing them not only made the body an object of awareness, but also distanced it (Leder 1987: 189). The ailing body, now distanced, became the focus of an interpretative quest. In the Sugi Sakit, this quest involved 'viewing' or 'inspecting' (ngabas) the sick person and a gradual extension of the process of inspection to include ever more distant observers. The act of inspection aroused feelings of compassion and sympathy so that the patient's body became not only an object of inspection, but also a focus of action. To care for a patient was to be present, so that the sick person was never allowed to lapse into a disconnected state of personal isolation. Initially, when someone fell ill, those who responded first were typically neighbours and members of the sick person's family. To respond meant to intervene so as, literally, 'to view' or 'inspect the sick person' (ngabas orang ke sakit). In this visual language, the sick person's caregivers were said to respond by becoming ngintai, meaning 'watchful' or 'on the lookout'. ${ }^{21}$ Being watchful meant to enter a state of heightened vigilance. In this state, caregivers sought, for example, dreams-particularly dreams favourable to the sick person's prospects for recovery-or they went into the forest to seek omens or collect special foods favoured by the sick person to coax them back into eating. ${ }^{22}$ Outside the immediate family, for others, to demonstrate compassion meant bejalai, literally, 'to walk' or 'go on a journey', even if this journey was only to the neighbouring bilik (apartment). When other families learned that someone in the community had fallen ill, they typically responded by walking to the sick person's apartment 'to inspect' the patient. If the illness persisted, or appeared to be serious from

21 From the root intai, meaning 'wait' or 'watch for [an opportunity]' (Richards 1981: 117).

22 Loss of appetite is seen as both a symptom of illness and a sign that the patient may have lost their will to live. Hence, every effort is made to encourage the patient to resume eating. 
the outset, family members were generally dispatched to surrounding longhouses to inform close relatives and friends. In this way, the circle of visitors typically expanded.

At first, a person was often unsure as to the cause of their illness or how to deal with it. Other family members and even the longhouse elders might also be uncertain. As an ever-expanding circle of visitors arrived to 'inspect' the sick person, their visits prompted an increasingly public discussion of the symptoms and circumstances of the patient's illness. In this way, the sick person's personal plight quickly became a matter of shared concern and discussion. The patient's illness, its possible causes and how it might be treated became topics of an ever-widening conversation. If, out of these visits, the sick person's family decided to summon a priest bard, the decision itself was preceded by a general meeting of longhouse members (aum), the major purpose of which was to achieve a further level of shared consensus and clarity.

In this way, the familiar institutions of travelling, visiting and hospitality became the basis on which the Sugi Sakit was socially organised. During the ritual, relationships between visitors and hosts assumed an increasingly formalised character, undergoing what Bell (1997: 81) has called a process of 'ritualisation'. To begin the process, the arrival of the priest bard on the day of the ritual signalled the appearance of a person of recognised ritual authority. Priest bards in the Saribas were generally revered figures and were welcomed by their hosts as honoured guests. Their relationship with the sponsoring families- 'those who owned the work' (sida' ke empuka pengawa') — was based on a division of labour in which the priest bard, using his main, invoked a participating audience of unseen visitors, while the sponsors, for their part, assembled a corresponding audience of invited human guests. The human participants in the Sugi Sakit were divided, again, into hosts and guests. The hosts included the families of those who 'owned' the ritual, their kindred (kaban belayan) who came, sometimes from other communities, to assist them and other members of the sick person's longhouse. The most important guests were the owners' pengabang ('invited guests') coming from other longhouses. At the beginning of the ritual, the welcoming of the human pengabang formed a prelude to the welcoming of the unseen guests. Their reception typically began in the early afternoon and ended at sundown. The invocation of unseen pengabang began soon after dark and ended with the arrival of Bujang Sugi and his unseen pengabang from beyond the human world just before sunrise. 


\section{Eros and ritual storytelling}

Following the offering ceremony mentioned earlier, the Sugi Sakit was temporarily suspended for an evening meal, served by the sponsoring families to their guests along the outer gallery (pantar). As soon as the meal was over, the priest bard resumed his work, first singing a prologue called the sempalai. ${ }^{23}$ The sempalai was a playful interlude meant to capture his audience's attention. It also served as a transition to the more serious work that followed. In this prologue, the priest bard described his sempalai as a praise song sung in honour of the meligai. But here, he referred to this structure, not in the special language of a priest bard, but by its common language meaning, to refer to the traditional sleeping place of young unmarried women. It now became in his main the bed of a maiden and its walls of ritual cloth became a mosquito curtain.

Traditionally, in coming of age, young women ceased to sleep in the family apartment and moved to a raised sleeping platform immediately above it in the loft. This was partially enclosed for privacy. Here, late at night, after everyone in the longhouse was assumed to have gone to sleep, young women were free to receive male suitors and engage in nightly courting. Young unmarried men also moved from the family apartment and slept on the outer section of the gallery, which, in the distant past and in the stories of the Orang Panggau, was also elevated and so was called the panggau. ${ }^{24}$ The Iban described courting as a form of 'visiting' (v.f., nguang, guang, n.f.). 'Courting bachelors' (bujang nguang) visiting from other longhouses also slept on the panggau and from there it was relatively easy to climb to the lofts without disturbing those asleep in the family apartment. Traditionally, courting was conducted in the dark. Hence, the common term used to describe it was ngayap, meaning, literally, 'to grope in the dark'. If a young woman wished to be left undisturbed, she left a small oil lamp burning by her bedside, indicating that she did not wish to be courted. On the surface, the fact that courting took place in the dark would seem to contradict the notion that visibility activates love. On the contrary, however, it was a direct reflection of this notion. For young people of both sexes, one of the objectives of visiting was 'to inspect' and 'be seen' by possible romantic partners. In initiating a night-time

23 The term sempalai derives from the root word empalai, meaning, literally, 'a fenced garden' (Richards 1981: 380).

24 In a modern Iban longhouse, this part of the gallery, which is no longer raised, is called the pantar or penyurai. 
romance, a young man initially presented himself as a stranger, much like Bujang Sugi in the Sugi epic. For a young woman, a primary object was to overcome the initial anonymity of her suitor, so that, if he were serious and the relationship seemed likely to deepen, he was compelled to reveal his identity and so make himself visible, ultimately, not only to the young woman herself, but also to her family, through a proposal of marriage.

In his sempalai, the priest bard, in addition to praising the meligai, described in poetic language the immediate setting. Night had fallen and surrounding him on the gallery were throngs of handsome bachelors and beautiful maidens. The latter urged him to sing a love song, which he was compelled to do at the request of his clients. Without a break, he shifted from the prologue to a new song called the ngadingka lemambang (to introduce the priest bard) in which he summoned his spirit helpers. As he sang, he shifted the perspective of his main from the here-andnow setting of the longhouse, the plight of his patient and the mood of his audience, to the unseen world, where, as he sang, the gods and spirits were described as gazing down from above and so taking note of the meligai and the activities unfolding on the gallery. He then called for the descent of the shaman gods (petara manang) and, as soon as they had finished treating the patient, he returned to his swing and began to sing the story of Sugi and Sedinang. As indicated by Dari and the other elders, the telling of this story was, for the priest bard's audience, the high point of the ritual.

Storytelling (becherita) was thus a central feature of the Sugi Sakit. It was also critical to the ritual's emotional impact. 'Emotions', as Andrew Beatty asserts, 'implicate narrative, and vice versa' (2014: 558). Narratives provide the time dimension needed for the development and playing out of emotions, while emotion-eliciting situations are the primary subject matter of narratives (Beatty 2010). The principal hero of the Sugi story is portrayed as a miraculous healer, who is able to bring back to life even the enemies he has decapitated in battle. He and Maiden Sedinang, as Keling and Kumang, represent the epitome of masculine and feminine beauty, their very perfection itself acting in the story as a source of healing power. Like love charms, they embody pemandang; to behold them is to be drawn to them. The effect of the Sugi story was thus to reawaken the listeners' attachment to the living world and to the physical pleasures and experiences that made life in this world worth living. The aesthetic beauty of the story, the hyperbole and the dramatic, vivid way in which it was performed caused listeners to 'feel' or 'experience love' (asai rindu') 
directly as an emotional response to what they were hearing and seeing. For the patient, the Sugi story opened their awareness to an imaginary world, beyond pain, fear or the infirmities of the body, while, at the same time, it restored their connections with the past, evoking memories of youth, and with a possible future free of bodily affliction. The Sugi Sakit brought about an emotional transformation in both the patient and the social community who assembled to take part in it. From an initial state of worry and grieving, the community was mobilised, united in a common purpose and motivated by shared feelings of compassion and gladness evoked by the priest bard's main, greetings and rites of hospitality, and by the spectacle of the ritual itself. The patient, too, was transformed. Brought into the ritual as an ageing, and often very ill, patient, he or she became, through identification with the heroes and heroines of the Sugi epic, a young man or woman in the prime of life, a victorious warrior or a maiden being courted.

Here, the aesthetics of beauty, the capacity of persons or things to give pleasure, was bound up with the embodied experience of what it meant to be alive, in good health and actively engaged in the external world. In her book On Beauty and Being Just (1999), Elaine Scarry attempts to define what occurs when someone sees or hears something they experience as beautiful. While beauty itself is beyond definition, the perceiver, in encountering it, experiences it immediately as such. One common metaphor compares the response to a greeting. Beauty, when we encounter it, whether in a person or an object, causes 'unease and indifference [to] drop away [so that] the world of existence loses its capacity to harm'. When we stand in the presence of something beautiful, 'it makes life more vivid, animated, worth living' (Scarry 1999: 24-5). Beauty, moreover, has a 'forward momentum'-it engages us with the world and incites us to contemplation and to bringing new things into being. It thus reinforces the inherent tendency of the healthy, lived-in embodied self to project itself into the world and to seek to apprehend and act on whatever the bodily senses perceive to be present there. When one beholds a beautiful person, or a beautiful object, even if this object is inanimate, the beholder, Scarry tells us, confers on it a 'surfeit of aliveness' (1999: 89). This conferral involves 'a reciprocal pact'. The perceiver confers the gift of life on what he or she experiences as beautiful, while the beautiful thing or person confers the gift of life on the perceiver. 
During the Sugi Sakit, all of this was reinforced by the physical setting in which the ritual took place, represented, in particular, by the meligai. For males, the platform inside this structure represented the panggau, the raised sleeping platform of visitors and of the bachelor heroes of the Sugi epic, while, for women, it symbolised the sleeping place of the maiden heroines, the site of courtship and love affairs. As the ritual's visible focus, it evoked the life-restoring powers of love in all the varied forms described here, from gladness to eros.

\section{References}

Averill, James R. 1985. 'The social construction of emotion: With special reference to love'. In Kenneth J. Gergen and Keith E. Davis (eds) The Social Construction of the Person, pp. 89-109. New York: SpringerVerlag. doi.org/10.1007/978-1-4612-5076-0_5.

Barrett, Robert J. 1993. 'Performance, effectiveness and the Iban manang'. In Robert L. Winzeler (ed.) The Seen and the Unseen: Shamanism, mediumship and possession in Borneo, pp. 235-79. Monograph 2. Williamsburg, VA: Borneo Research Council.

Barrett, Robert J. 2012. Psychiatric Research among the Iban: Collected papers of Robert J. Barrett. Monograph Series No. 13. Anna ChurHansen and George N. Appell (eds). Phillips, ME: Borneo Research Council.

Beatty, Andrew. 2005. 'Emotions in the field: What are we talking about?' Journal of the Royal Anthropological Institute 11: 17-37. doi.org/ 10.1111/j.1467-9655.2005.00224.x.

Beatty, Andrew. 2010. 'How did it feel for you? Emotion, narrative, and the limits of ethnography'. American Anthropologist 112: 430-43. doi.org/10.1111/j.1548-1433.2010.01250.x.

Beatty, Andrew. 2014. 'Anthropology and emotion'. Journal of the Royal Anthropological Institute 20: 545-63. doi.org/10.1111/14679655.12114.

Bell, Catherine. 1997. Ritual: Perspectives and dimensions. New York: Oxford University Press. 
Blust, Robert. 2013. The Austronesian Languages. Rev. edn. Canberra: Asia-Pacific Linguistics.

Bruggeman, G. 1985. English-Iban Vocabulary. Kuching: Persatuan Kesusasteraan Sarawak.

Csordas, Thomas J. 1990. 'Embodiment as a paradigm for anthropology'. Ethos 18: 5-47. doi.org/10.1525/eth.1990.18.1.02a00010.

Csordas, Thomas J. (ed.). 1996. Embodiment and Experience: The existential ground of culture and self. Cambridge: Cambridge University Press.

Department of Statistics Malaysia. 2012. Population Distribution and Basic Demographic Characteristic Report 2010. Kuala Lumpur: Department of Statistics Malaysia. Available from: www.dosm.gov. my/v1/index.php?r=column/cthemeByCat \&cat=117\&bul_id=MDM xdHZjWTk1SjFzTzNkRXYzcVZjdz09\&menu_id=L0pheU43NWJ wRWVSZklWdzQ4TlhUUT09 (accessed 25 September 2017).

Ensiring, Janang anak, Jantan Umbat and Robert Menua Saleh (compilers). 2011. Bup Sereba Reti Jaku Iban. [In Iban]. Kuching: Tun Jugah Foundation.

Fox, James J. 1995. 'Austronesian societies and their transformations'. In Peter Bellwood, James J. Fox and Darrell Tryon (eds) The Austronesians: Historical and comparative perspectives, pp. 214-28. Canberra: The Australian National University.

Fox, James J. 2008. 'Installing the "outsider" inside: The exploration of an epistemic Austronesian cultural theme and its social significance'. Indonesia and the Malay World 36(105): 201-18. doi.org/ 10.1080/13639810802267942.

Freeman, Derek. 1967. 'Shaman and incubus'. Psychoanalytic Study of Society 4: 315-44.

Freeman, Derek. 1981. Some reflections on the nature of Iban society. Occasional Papers, Department of Anthropology, Research School of Pacific Studies. Canberra: The Australian National University.

Goddard, Cliff. 1995. "Cognitive mapping” or "verbal explication"? Understanding love on the Malay Archipelago'. Semiotica 106(3-4): 323-54. 
Goddard, Cliff. 2001. 'Hati: A key word in the Malay vocabulary of emotion'. In Jean Harkins and Anna Wierzbicka (eds) Emotions in Crosslinguistic Perspective, pp. 167-96. New York: Mouton de Gruyter. doi.org/10.1515/9783110880168.167.

Howell, William and D. J. S. Bailey. 1900. A Sea Dyak Dictionary. Singapore: The American Mission Press.

Kapferer, Bruce. 1979. 'Emotion and feeling in Sinhalese healing rites'. Social Analysis 1: 153-76.

Kapferer, Bruce. 1995. 'From the edge of death: Sorcery and the motion of consciousness'. In Anthony P. Cohen and Nigel Rapport (eds) Questions of Consciousness, pp. 134-52. New York: Routledge. doi.org/ 10.4324/9780203449486_chapter_7.

Karim, Wazir Jahan (ed.). 1990. Emotions of Culture: A Malay perspective. Singapore: Oxford University Press.

Leder, Drew Lance. 1987. 'The absent body: A phenomenological anatomy'. PhD dissertation. State University of New York at Stony Brook, NY.

Levy, Robert. 1973. Tabitians: Mind and experience in the Society Islands. Chicago: University of Chicago Press.

Levy, Robert. 1984. 'Emotion, knowing, and culture'. In Richard A. Shweder and Robert A. LeVine (eds) Culture Theory: Essays on mind, self and emotion, pp. 214-37. Cambridge: Cambridge University Press.

Lutz, Catherine A. 1988. Unnatural Emotions: Everyday sentiments on a Micronesian atoll and their challenge to Western theory. Chicago: University of Chicago Press.

Lutz, Catherine A. and Geoffrey M. White. 1986. 'The anthropology of emotions'. Annual Review of Anthropology 15: 405-36. doi.org/ 10.1146/annurev.an.15.100186.002201.

Matisoff, James. 1986. 'Hearts and minds in South-East Asian languages and English: An essay in the comparative lexical semantics of psychocollocations'. Cahiers de linguistique-Asie Orientale 15(1): 5-57. doi.org/10.3406/clao.1986.1191. 
Richards, Anthony. 1981. An Iban-English Dictionary. Oxford: Oxford University Press.

Rosaldo, Michelle. 1984. 'Toward an anthropology of self and feeling'. In Richard A. Shweder and Robert A. LeVine (eds) Culture Theory: Essays on mind, self and emotion, pp. 137-57. Cambridge: Cambridge University Press.

Sahlins, Marshall. 1981. 'The stranger king: Or Dumézil among the Fijians'. Journal of Pacific History 16: 107-32. doi.org/10.1080/ 00223348108572419.

Sahlins, Marshall. 1985. Islands of History. Chicago: University of Chicago Press.

Sahlins, Marshall. 2008. 'The stranger-king: Or, elementary forms of the politics of life'. Indonesia and the Malay World 36(105): 177-99. doi.org/10.1080/13639810802267918.

Sahlins, Marshall. 2012. 'Alterity and autochthony: Austronesian cosmologies of the marvelous'. HAU: Journal of Ethnographic Theory 2(1): 131-60. doi.org/10.14318/hau2.1.008.

Sather, Clifford. 1978. 'The malevolent koklir: Iban concepts of sexual peril and the dangers of childbirth'. Bijdragen tot de Taal-, Landen Volkenkunde 134: 310-55. doi.org/10.1163/22134379-90002590.

Sather, Clifford. 1992. 'The rites of manggol: Work and ritual in Paku Iban agriculture'. Sarawak Museum Journal 40: 107-34.

Sather, Clifford. 1993. 'Posts, hearths and thresholds: The Iban longhouse as a ritual structure'. In James J. Fox (ed.) Inside Austronesian Houses: Perspectives on domestic designs for living, pp. 65-115. Canberra: The Australian National University.

Sather, Clifford. 1994. 'Wooden weapons: Constrained violence and the evolution of adat in a nineteenth-century Iban society'. ASSESS Journal 1: 5-23.

Sather, Clifford. 1996. "All threads are white": Iban egalitarianism reconsidered'. In James J. Fox and Clifford Sather (eds) Origins, Ancestry and Alliance, pp. 70-110. Canberra: The Australian National University. 
Sather, Clifford. 1997. The Bajau Laut: Adaptation, history, and fate in a maritime fishing society of south-eastern Sabah. Kuala Lumpur: Oxford University Press.

Sather, Clifford. 2001. Seeds of Play, Words of Power: An ethnographic study of Iban shamanic chants. Kuching: Tun Jugah Foundation and Borneo Research Council.

Sather, Clifford. 2004. 'The Iban'. In Ooi Keat Gin (ed.) Southeast Asia: A Historical Encyclopedia. Volume 2, pp. 623-5. Santa Barbara, CA: ABC Clio Press.

Sather, Clifford. 2012a. 'Introduction'. In Anna Chur-Hansen and George N. Appell (eds) Psychiatric Research among the Iban: Collected papers of Robert J. Barrett, pp. x-xxxvi. Monograph Series No. 13. Phillips, ME: Borneo Research Council.

Sather, Clifford. 2012b. 'Recalling the dead, revering the ancestors: Multiple forms of ancestorship in Saribas Iban society'. In Pascal Couderc and Kenneth Sillander (eds) Ancestors in Borneo Societies: Death, transformation, and social immortality, pp. 114-52. Copenhagen: NIAS Press.

Sather, Clifford. 2017. A Borneo Healing Romance: Ritual Storytelling and the Sugi Sakit, A Saribas Iban Rite of Healing. Phillips, ME/Sarawak, Malaysia: Borneo Research Council/The Tun Jugah Foundation.

Sather, Clifford and Jantan Umbat. 2004. Ripih Pengawa' Besugi Sakit. Unpublished transcription of the Sugi Sakit performed by Lemambang Renang anak Jabing. Iban Archives Collection. Tun Jugah Foundation, Kuching.

Scarry, Elaine. 1985. The Body in Pain: The Making and Unmaking of the World. New York: Oxford University Press.

Scarry, Elaine. 1999. On Beauty and Being Just. Princeton, NJ: Princeton University Press.

Scott, N. C. 1956. A Dictionary of Sea Dayak. London: School of Oriental and African Studies, University of London.

Shweder, Richard A. and Robert A. LeVine (eds). 1984. Culture Theory: Essays on mind, self and emotion. Cambridge: Cambridge University Press. 
Sutlive, Vinson and Joanne Sutlive (eds). 1994. A Handy Reference Dictionary of Iban and English. Kuching: Tun Jugah Foundation.

Urban, Greg. 1996. Metaphysical Community: The interplay of the senses and the intellect. Austin: University of Texas Press.

Wadley, Reed L. 2004. 'Punitive expeditions and divine revenge: Oral and colonial histories of rebellion and pacification in western Borneo, 1886-1902'. Ethnohistory 51(3): 609-36. doi.org/10.1215/0014180151-3-609.

Wadley, Reed L. and Fredrik Kuyah. 2001. 'Iban communities in West Kalimantan'. In Vinson Sutlive and Joanne Sutlive (eds) The Encyclopaedia of Iban Studies. Volume 2, pp. 716-34. Kuching: Tun Jugah Foundation.

Wilce, J. M. 2004. 'Passionate scholarship: Recent anthropologies of emotion'. Reviews in Anthropology 33: 1-7.

Wolters, O. W. 1999. History, culture, and region in Southeast Asian perspectives. Studies on Southeast Asia No. 26. Ithaca, NY: Cornell Southeast Asia Program Publications. 
This text is taken from Expressions of Austronesian Thought and Emotions, edited by James J. Fox, published 2018 by ANU Press, The Australian National University, Canberra, Australia.

doi.org/10.22459/EATE.04.2018.03 